\title{
THE APPLICATION OF ROUTING OF OSPF AND EIGRP USING THE METHOD REDISTRIBUTE TO IMPROVE THE EFFICIENCY OF THE NETWORK
}

\author{
Ari Ramadhan Wibowo ${ }^{1}$, Anton ${ }^{2}$, Puji Astuti ${ }^{3}$ \\ Study Program Of Informatics Engineering \\ Sekolah Tinggi Manajemen Informatika dan Komputer Nusa Mandiri \\ ari.ramadan98@gmail.com, anton@nusamandiri.ac.id, puji.pat@nusamandiri.ac.id
}

\begin{abstract}
Abstrak
CV. Cyber Art Group Indonesia adalah Head Office di wilayah Ciputat, Tengerang Selatan yang bergerak di bidang Wedding Organizer dan mempunyai satu cabang di wilayah Depok Jawa Barat. Saat ini antara cabang dan head office dalam pengambilan dan pengiriman data dilakukan lewat email. Dan di cabang belum tersedianya local network, local network hanya ada di head office. Apabila ingin mengambil atau mengirim, pihak marketing di cabang menghubungi kantor pusat untuk mengirimkan file, hal ini membuat kendala bagi karyawan baik di cabang maupun head office. Karna semua data sudah tersimpan di server pusat, apabila ada kebutuhan dapat diambil kapan saja. Maka untuk itu peneliti disini membuat jaringan local antara kantor cabang dengan head office. Dengan menggunakan metode Redistribution Router pengambilan dan pengiriman data ke server dapat terlihat waktunya apakah lebih cepat dengan menggunakan parameter pengukuran Throughput, Delay dan Packetloss. Menghubungkan beberapa router sebagai gatewaynya serta menerapkan routing OSPF dan EIGRP menjadikan transfer data lebih mudah dan lebih efisien pada banyak router. Setelah terpasang jaringan local antara cabang dan head office dilakukan testing dengan ukuran paket 32 byte yaitu 100\%. Untuk nilai Packet loss dengan ukuran paket sebanyak 32 bytes pada percobaan pertama dan kedua menghasilkan nilai $0 \%$, dimana tidak ada paket yang hilang.
\end{abstract}

Kata Kunci: Routing, OSPF, EIGRP, Redistribution.

\begin{abstract}
CV. Cyber Art Group Indonesia is the Head Office in the Ciputat area, South Tangerang which is engaged in wedding planning and has one branch in Depok, West Java. Currently, between branches and head offices, data retrieval, and data transmission is done via email. And in branches there is no local network available, the local network is only at the head office. If you want to pick up or send, the marketing at the branch contacts the head office to send files, this creates obstacles for employees both at the branch and head office. Because all data is stored on the central server, if there is a need, it can be retrieved at any time. So for that researchers here create a local network between the branch office and the head office. By using the Redistribution Router method, data retrieval and sending to the server can be seen whether the time is faster by using the Throughput, Delay, and Packet loss measurement parameters. Connecting multiple routers as gateways and implementing OSPF and EIGRP routing makes data transfer easier and more efficient on multiple routers. After installing the local network between the branch and the head office, it is tested with a package size of 32 bytes, namely 100\%. For the Packet loss value with a packet size of 32 bytes in the first and second experiments, it produces a value of $0 \%$, where no packet is lost.
\end{abstract}

Keywords: Routing, OSPF, EIGRP, Redistribution

\section{INTRODUCTION}

Computer networks provide the ability as a medium of communication that can accelerate the process work better in terms of time and space (Badrul, 2016). Also, information technology can make it easier to access information. The network allows the working group to communicate more efficiently. Letters and delivery of electronic messages are the substance most network systems, in addition to scheduling systems, project monitoring, online conferencing, and groupware, which all help teams work more productively (Munandar \& Badrul, 2015). CV. Cyber Art Group Indonesia, has a branch office that is not connected, between Head Office located in di Jl. Mualia no. 45 Serua, Ciputat, Tangerang Selatan, with a Branch Office di Jl. Raya KSU no.4 Tirta Jaya, Sukamaja, 
Depok, West Java. Given the need for the computer network so important in the office, especially for the exchange of data is quick and easy in doing the job, as well as to the process of data distribution and communication between a router with good. The current between the branches and head office in the retrieval and delivery of data via email. And in the branches of the unavailability of the local network, local network only exists in the head office. If you want to take or send, the marketing in the branches contact the central office to transmit the file, this makes the obstacle for the employees both in branches and head office. Because all data is already stored on the central server if their needs can be taken anytime. OSPF is one routing that is better, stronger, and faster than its predecessor. OSPF is also designed to go beyond the capabilities of the limitations of distance vector routing (Dwiyatno, Putra, \& Krisnaningsih, 2015). EIGRP is the routing protocol that is compliant with Cisco, disarm Algorithm (dual) (Purwanto, 2018). This protocol is known as a hybrid because it has routing Protocols Distance-Vector and LinkState (Achmad, 2017), (Manzoor, Hussain, \& Mehrban, 2020). The workings of the routing protocol EIGRP with how to calculate the cost metric using the delay, packet loss, and throughput as parameters (Astuti, Rizal, \& Wardani, 2019). The Differences in the characteristics of routing protocols that can be solved by using the redistribution router (Mukmin \& Negara, 2019). Routing protocol EIGRP, and OSP is a dynamic routing algorithm (Al Noman \& Chowdhury, 2014) (Wahyudi, Syamsuar, \& Negara, 2017). The use of two routing aims to analyze the comparison of the routing dynamics, as well as figure out the routing, which is the best performance of the different Autonomous System (AS) with the method of Redistribution (Mukmin, Antoni, \& Negara, 2016).

In addressing a computer network is certainly a necessary prediction of the development of a computer network, including in terms of overcoming the occurrence of differences in the application of the routing protocol. The difference in the application of the routing protocol will result in disruption of the performance of a computer network (Masykur, 2016). Redistribution Router is the method that the router can learn the route that is different from every routing and get optimal communication in which the many routing protocols that are being used (Manzoor et al., 2020). Also, redistribute is a method used to combine the type of routing protocol that can connect (Sari, Wijaya, Teknik, Komputer, \& Darma, 2017). This method is needed in a company which is building branches of one and the headquarters building is not yet connected.
In designing a network proposal with the methods of redistribution using the app Cisco Packet Tracer (Pantu, Iswahyudi, \& Rachmawati K, 2015). The purpose of this research is to propose a method Redistributed to combine the two routings, OSPF and EIGRP to connect and design a computer network efficiency as well as facilitate the employee's CV. Cyber Art Group Indonesia in exchanging data.

\section{RESEARCH METHODS}

As for the material in the collection of data.

The authors include the following.

1. Observation, to do a review directly from observation and recording in the field.

2. Interviews, data collection is done by asking directly to Aldo Inspiration as IT Support at CV. Cyber Art Group Indonesia

3. Literature, taking reference from various sources, either through books, journals, and information on the internet

There's some point in the analysis of this research, among others (Pratama, 2019):

\section{Needs Analysis}

Needs analysis in the application of routing of OSPF and RIGRP with the concept of redistribution, the author requires software Cisco Packet Tracer as a medium to run the simulation.

\section{Design}

Designing the network such as network topology and design, network proposal with the methods of redistribution using the app Cisco Packet Tracer.

\section{Testing}

This test is performed to determine whether the system has been running well. The early stages of testing this is a network with 2 routings is different to prove the connection can not be connected before using the method of redistribution, and the final stage in this research is with testing that already uses such methods.

\section{Implementation}

This system will connect the 2 routings on the router are connected and perform a configuration to enable a method of redistribution.

\section{Types Of Research}

This research type is quantitative data with observation and interviews (Sugiyono, 2015).

\section{Time and Place Research}


The time required for researchers to begin the observation to take into account the bandwidth that will be attached between the head office to the branch office for March until April 2020.

\section{Research Targets/Subjects}

The target in this research can connect the local network between the head office to the branch office were later in the delivery or retrieval of the data on the server can be easily done using the local network which is already connected.

\section{Research Steps}

\section{Steps of Preparation}

The initial step of this research sees the problem, find methods for solving problems, looking for a hypothesis for finding a solution, data collection, analysis of data, and conclusions of the research.

\section{Steps Of Data Collection}

Seek information through interviews with IT as well as see the router and local network as well as network topology used in the head office.

\section{Steps of Data Analysis}

At this stage the authors use quantitative data where a local network in the head office will connect the local network to another branch office by using the router configuration, then it will get a calculation in the retrieval and delivery of data to the server in the head office.

\section{Testing Steps}

During testing, this testing will be conducted on the local network between the Head office and branch offices. Where the delivery of data by checking the router configuration and bandwidth by using 2 computers.
This stage is the final stage of this research. Were the results the end gets a solution, as well as suggestions from the research that has been made.

\section{Data, Instrument, and Data Collection Techniques}

The data are seen in this research that how much casual optical fiber is used, and how the speed of data transfer is seen from the network topology.

\section{Data Analysis Techniques}

In this research there are steps in data collection and information:

\section{A. Needs Analysis}

Needs analysis in the application of routing of OSPF and EIGRP with the concept of redistribution, the author requires software Cisco Packet Tracer as a medium to run the simulation. Cisco Packet Tracer is an application developed by Cisco Company, the goal is to perform simulation of computer networks and to perform network monitoring computers that are running. As for the drawbacks in this application, i.e., device (device) that is provided only Cisco devices (Switch, Hub, Router) (Purwanto, 2018). Cisco Packet Tracer can be supported by the concept of Redistribution which the authors propose a prior is directly applied at the network that is running because in the Software is complete.

\section{B. Design}

Designing the network such as network topology and design, network proposal with the methods of redistribution using the app Cisco Packet Tracer.

\section{Steps Of Result and Suggestion}

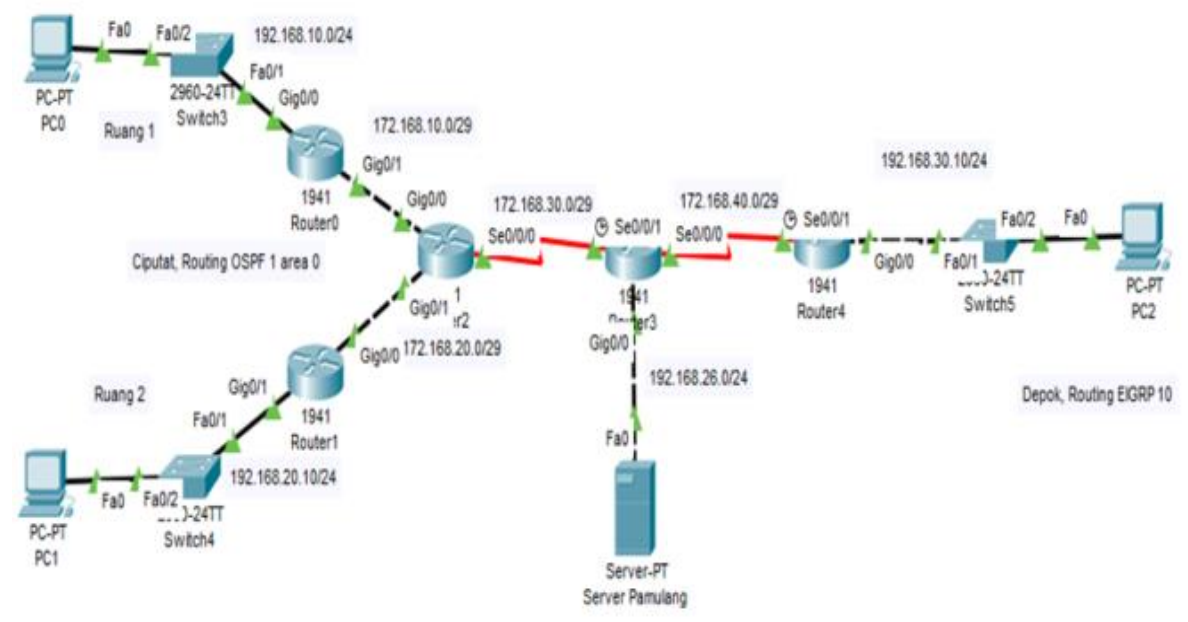

Figure 2. Scheme Network Proposal 
On the scheme of the network proposed in figure 2, the author added some routers. Where the addition of a new network for a Branch Office located in Depok, to the router using the Cisco router and Mikrotik as a medium to connect to other networks or existing. In this network, the author leaves some cable that is wired Straight, cross, and Fiber Optics (FO). For the use of connecting cables between the branch office and the central office using Fiber Optic (FO) to keep the access speed of data transfer. While in each building using UTP cable cat 6. With the network that the authors propose is, has advantages in networks where previously only one office has a network, now the second office has a network and connect.

\section{Testing}

a. Network Testing Early

At this stage, the authors do testing on the network topology that was available on the $\mathrm{CV}$. Cyber Art Group.

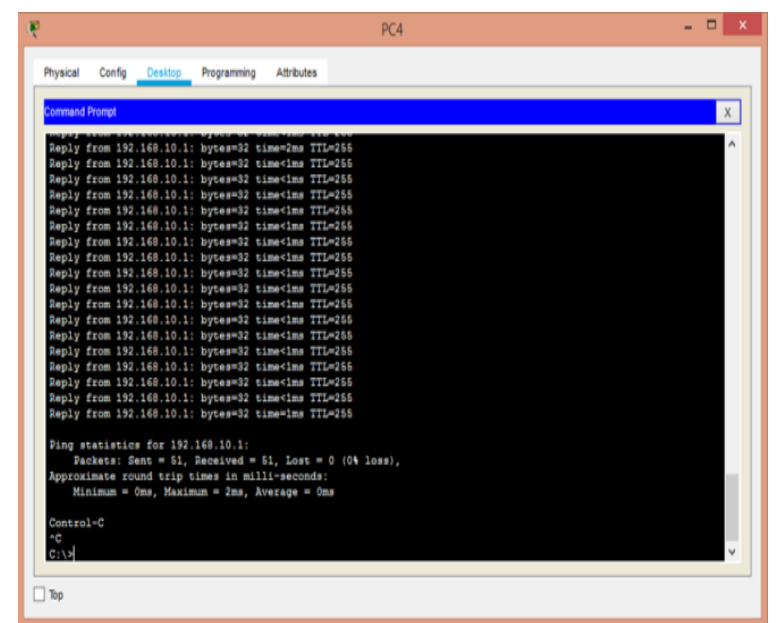

Figure 3. The repetition of the Ping the PC Office on a Router 51 times

From the test results figure, 3 is not getting a problem in the form of damages or performance at each network interface CV. Cyber Art Group. But in the event of a merger of the network conducted CV. Cyber Art Group, between Head Office with Branch Office Will, create a new network that produces the addition of track and area. Incorporation in this network is required to add a router. The increasing number of routers is used, then the information will increase the time. So it takes the routing process and the distribution of that good. Then the authors apply the routing protocol OSPF and EIGRP with the method of Redistribution on the network topology at CV. Cyber Art Group.

b. Testing The Network End
That the routing of OSPF and EIGRP with Redistribution goes well, at this stage, the authors perform the configuration on each router with the Command Line Interface (CLI). As for the configuration of routing of OSPF and EIGRP on each router in the network topology proposal that has been made.

1. Configuration Routing OSPF on Router2

Router >enable

Router\#configuration terminal

Router(config)\#router ospf 1

Router(config-router)\#net 172.168.10.0 0.0.0.7

area 0

Router(config-router)\#net 172.168.20.0 0.0.0.7

area 0

Router(config-router)\#net 172.168.30.0 0.0.0.7

area 0

Router(config-router)\#ex

Router(config)\#

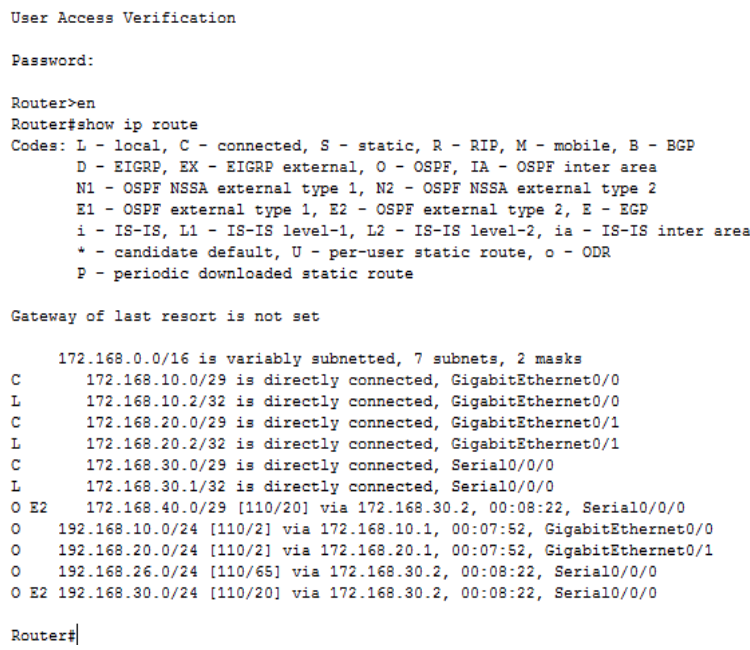

Figure 4. Routing Protocol OSPF Router2

From the results of testing in figure 4, the routing protocol OSPF on Router2 has been connected with the routing protocol EIGRP. The network Can be seen 172.168.40.0 already connected through IP address 172.168.30.2 to port Serial0/0/0. So also with network 192.168.30.0 already connected with IP address 172.168.30.2 to port Serial0/0/0.

\section{Configuration Routing OSPF pada Router3}

Router $>$ enable

Router\#configuration terminal

Router(config)\#router ospf 1

Router(config-router)\#net 172.168.30.0 0.0.0.7

area 0

Router(config-router)\#ex

Router(config)\# 
JURNAL RISET INFORMATIKA

Vol. 2, No. 4 September 2020
P-ISSN: 2656-1743 |E-ISSN: 2656-1735

DOI: https://doi.org/10.34288/jri.v2i4.158
3. Configuration routing EIGRP pada Router3 Router>enable

Router\#configuration terminal

Router(config)\#router eigrp 10

Router(config-router)\#net 172.168.40.0 0.0.0.7

Router(config-router)\#ex

Router(config)\#

4. Configuration routing EIGRP pada Router4 Router $>$ enable

Router\#configuration terminal

Router(config)\#router eigrp 10

Router(config-router)\#net 192.168.30.10 0.0.0.255

Router(config-router)\#net 172.168.40.0 0.0.0.7

Router(config-router)\#ex

Router(config)\#

User Access Verification

Password:

Router>en

Codes: $I$ - locil $C$ - connected, S - static, $R$ - RIP, M - mobile, B - BGP

D - EIGRP, EX - EIGRP externa1, 0 - OSPF, IA - OSPF inter area

N1 - OSPF NSSA external type 1, N2 - OSPF NSSA external type 2

81 - OSPF external type $1, \mathrm{E} 2$ - OSPF external type $2, \mathrm{E}-\mathrm{E} G \mathrm{P}$

- IS-IS, L1 - IS-IS leve1-1, L2 - IS-IS leve1-2, ia - IS-IS inter are

- candidate default, $U$ - per-user ataric route, 0 - ODR

- periodic downloaded static route

Gateway of last resort is not get

172.168.0.0/16 is variably subnetted, 5 subnets, 2 masks

DX 172.168.10.0/29 [170/2560512256] via $172.168 .40 .1,00: 12.14$, Serialo/0/1

D EX 172.168.20.0/29 [170/2560512256] via $172.168 .40 .1,00: 12: 14$, Serialo/0/

D EX 172.168.30.0/29 [170/2560512256] via 172.168.40.1, 00:12:58, Seria10/0/1

$172.168 .40 .0 / 29$ is directly connected, Serial0/0/1

$172.168 .40 .2 / 32$ is directly connected, Serialo/0

D EX 192.168.10.0/24 [170/2560512256] via 172.168.40.1, 00:12:14, Seria10/0/1

D EX 192.168.20.0/24 [170/2560512256] via 172.168.40.1, 00:12:14, Seria10/0/

$192.168 .26 .0 / 24[90 / 2172416]$ via $172.168 .40 .1,00: 12: 59$, Seria10/0/1

$92.168 .30 .0 / 24$ is variably subnetted, 2 subnets, 2 masks

$192.168 .30 .11 / 32$ is directly connected, GigabitZthernet0/0 Router $¥$

Figure 5. Routing Protocol EIGRP Router4

\section{Implementation}

In figure 6 the Process of Routing Redistribution Router3 is done to the link between Router2 and Router4. Where each Router has a Routing Protocol different. Router2 uses the Routing Protocol OSPF, while router4 using the Routing Protocol EIGRP.

1. Configuration Redistribution pada Router3

Router $>$ enable

Router\#configuration terminal

Router(config)\#router ospf 1

Router(config-router)\#redistribute eigrp

10subnets

Router(config-router)\#ex

Router(config)\#router eigrp 10

Router(config-router)\#redistribute ospf 1 metric 1

1111

Router(config-if)\#ex

Router(config)\#

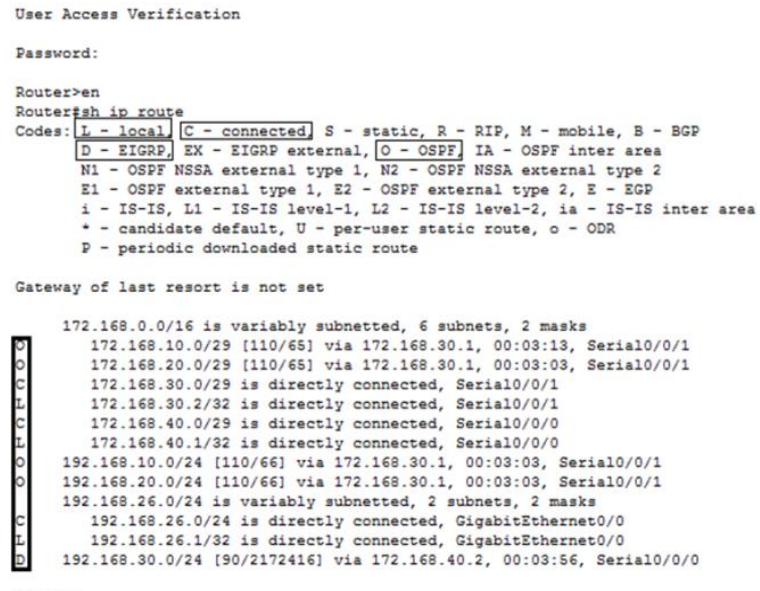

Figure 6. Routing Redistribution in Router3

In Testing the Network End, the Author re-test the network using Ping and Traceroute on each router to the client or vice versa. As an example of the author doing a traceroute through PC0 in Ciputat towards PC2 in Depok. Figure 7 results of traceroute, PC0 Through 5 hops to reach PC2.

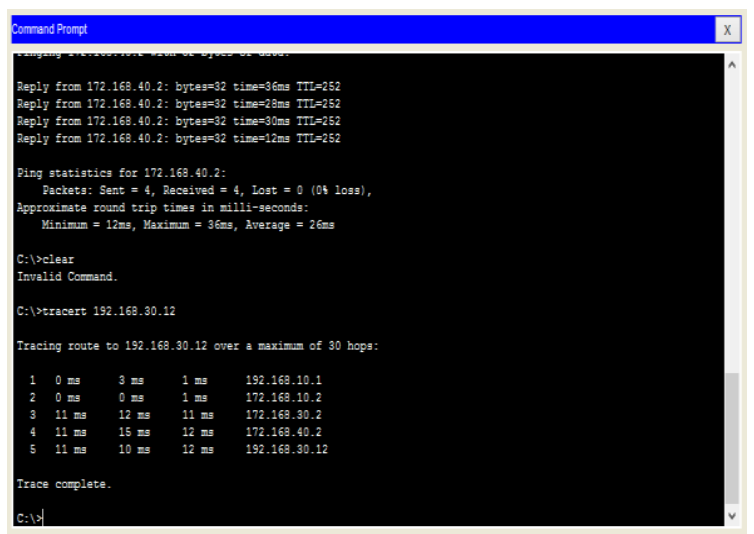

Figure 7. Hasil Traceroute from PC0 to PC2

Figure 8 one of the tests taken from PC0 by using Ping to the direction of the Gateway that also router 0 . And the result is normal.

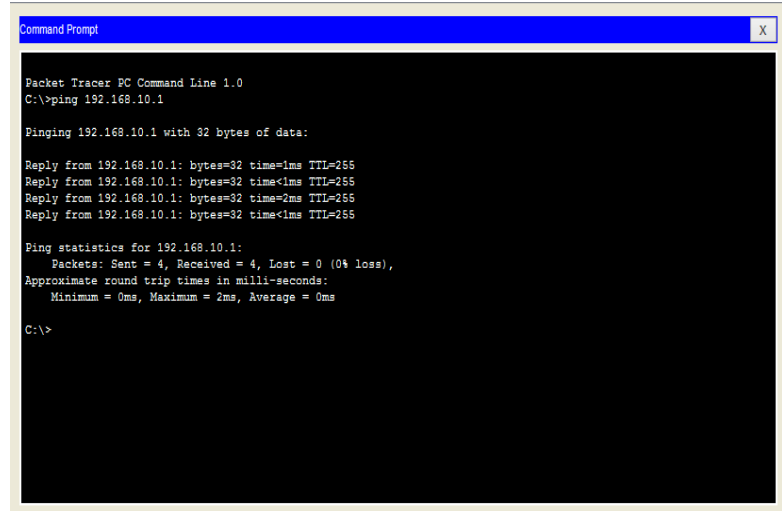

Figure 8. Hasil test ping from Router0 


\section{RESEARCH RESULT AND DISCUSSION}

The scheme of the network used in the CV. Cyber ART Group Indonesia is a Point to MultiPoint.

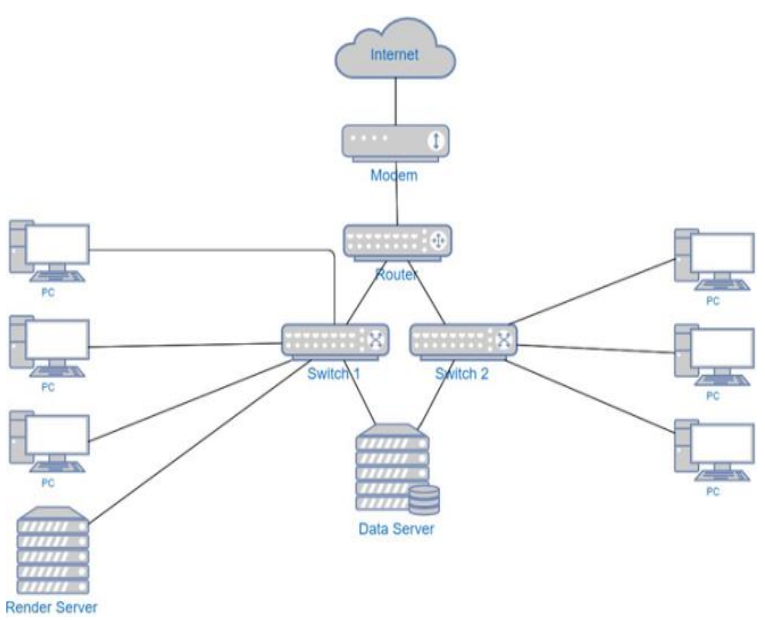

Figure 1. The Scheme Of The Network Running

Figure 1 The scheme of the network on the CV. Cyber Art Group Indonesia, this Network includes only one area of the course. Where includes only the Head Office located in Jl. Mualia no. 45 Serua, Ciputat, South Tangerang, and yet connected in the Brach Office, which is located in Jl. Raya KSU no.4 Tirta Jaya, Sukamaja, Depok, West Java. Given the need for the computer network so important in the office, especially for the exchange of data is quick and easy in doing the job, as well as to the process of data distribution and communication between a router with good. To overcome the above problems need the construction of a new design so that the computer network in each unit can be connected and can work optimally. In the discussion on the Scheme of the Network Running in the CV. Cyber Art Group Indonesia there is some discussion that the author has prepared, discussing the Topology, Architecture, Network Scheme proposal.

In the experiment that has the author created previously, the model, QoS is used for the measurement of parameters throughput, delay, packet loss on each routing in testing communication 1 and 2 with a given load 32bit. From the above explanation, the experiment is the measurement of the parameters QoS which consists of throughput, delay, and packet loss as follows (Mukmin et al., 2016).

In the trials can be seen the throughput with a packet size of 32 bytes in the first experiment, namely $100 \%$. While on trial to two $98 \%$, only a difference of $2 \%$ with the first experiment. To test the first value of the delay with the packet size as much as 32 byte has an average rating of $14 \mathrm{~ms}$, while in the second trial have the results of the average value of $16 \mathrm{~ms}$. And the last, to the value of the Packet loss with packet size as much as 32 bytes in the first experiment, and the second generates a value of $0 \%$, where no packets are lost in this trial. Result QoS on the Redistribution EIGRP to OSPF can be seen in table 1 , table 2 , and table 3 .

Table 1 Value of the throughput EIGRP Redistribution OSPF

\begin{tabular}{lcrrr}
\hline Package & & \multicolumn{3}{c}{ Throughput } \\
\cline { 3 - 5 } $\begin{array}{c}\text { Size } \\
\text { (Bytes) }\end{array}$ & Testing & Sent & Received(\%) & Lost(\%) \\
\hline 32 & 1 & 67 & $67(100 \%)$ & $0(0 \%)$ \\
\hline 32 & 2 & 74 & $73(98 \%)$ & $1(2 \%)$ \\
\hline
\end{tabular}

Table 2 Value of Delay EIGRP Redistribution OSPF

\begin{tabular}{ccccc}
\hline \multirow{2}{*}{$\begin{array}{c}\text { Package Size } \\
\text { (Bytes) }\end{array}$} & Testing & \multicolumn{3}{c}{ Delay $(\mathrm{ms})$} \\
\cline { 3 - 5 } & & Min & Maks & Average \\
\hline 32 & 1 & $11 \mathrm{~ms}$ & $30 \mathrm{~ms}$ & $14 \mathrm{~ms}$ \\
\hline 32 & 2 & $11 \mathrm{~ms}$ & $85 \mathrm{~ms}$ & $16 \mathrm{~ms}$ \\
\hline
\end{tabular}

Table 3 Value of Packet Loss EIGRP Redistribution OSPF

\begin{tabular}{ccccc}
\hline $\begin{array}{c}\text { Packet size } \\
\text { (Bytes) }\end{array}$ & Testing & \multicolumn{3}{c}{ Packet loss(ms) } \\
\cline { 2 - 5 } & & Sent & Lost & Lost(\%) \\
\hline 32 & 1 & 19 & 0 & $0(\%)$ \\
\hline 32 & 2 & 20 & 0 & $0(\%)$ \\
\hline
\end{tabular}

\section{CONCLUSION AND SUGGESTIONS}

\section{Conclusion}

The use of Routing OSPF and EIGRP has been successful in doing on the mainline so that the process of sending data between the router goes well. With a packet size of 32 bytes, i.e. 100\%. For the value of Packet loss with packet size as 32 bytes in the first experiment and the second generates a value of $0 \%$, where no packets are lost. With the method of redistribution can connect some of the routings in the topology of the network. The method of redistribution to make the distribution between Routing OSPF and EIGRP, so it is better for the development of network topology in the CV. Cyber ART Group Indonesia.

\section{Suggestions}

The research that has been done might be able to use some of the routings of other OSPF and EIGRP, for example using Routing RIP, IS-IS, and BGP. In the experiment the delivery of the data 
package or use the device the router real allows get maximum results from the simulation results, Cisco Packet Tracer.

\section{REFERENSI}

Achmad, A. (2017). IMPLEMENTASI ROUTING EIGRP PADA JARINGAN KOMPUTER. Faktor Exacta, 9(4), 324-332. https://doi.org/10.30998/FAKTOREXACTA.V 9I4.1144

Al Noman, A., \& Chowdhury, A. (2014). Performance Analysis of EIGRP and OSPF for Different Applications using OPNET. Australasian Journal of Computer Science, 1(1), https://doi.org/10.3923/aujcs.2014.1.8

Astuti, I., Rizal, S., \& Wardani, K. R. N. (2019). Perbandingan Protokol Redistribusi Route Pada Jaringan Ipv6 ( Studi Kasus: Ripng , Eigrp for Ipv6 , Ospfv3 ). Bina Darma Conference on Computer Science (BDCCS), 1(1), 4149. Retrieved from http://conference.binadarma.ac.id/index.php /BDCCS/article/view/52

Badrul, M. (2016). Open VPN-Access Server Dengan Enskripsi SSL/TI Open SSL. INFORMATICS FOR EDUCATORS AND PROFESSIONAL : Journal of Informatics, 1(1), 1-12. Retrieved from http://ejournalbinainsani.ac.id/index.php/ITBI/article/view /138

Dwiyatno, S., Putra, G. W., \& Krisnaningsih, E. (2015). Penerapan Ospf Routing, DeMilitarized Zone, Dan Firewall Pada Mikrotik Routerboard Dinas Komunikasi Dan Informatika Depok 1). Jurnal Sistem Informasi, 2, 59-67. Retrieved from https://ejurnal.lppmunsera.org/index.php/jsii/article /view/70

Manzoor, A., Hussain, M., \& Mehrban, S. (2020). Performance Analysis and Route Optimization: Redistribution between EIGRP, OSPF \& BGP Routing Protocols. Computer Standards and Interfaces, 68. https://doi.org/10.1016/j.csi.2019.103391

Masykur, F. (2016). Penggabungan Antar Routing Protocol Menggunakan Teknik Redistribution. Prosiding SNATIF Ke-3 Tahun 2016, 39-42. Kudus: Universitas Muria
Kudus. $\quad$ Retrieved from https://jurnal.umk.ac.id/index.php/SNA/arti cle/view/623

Mukmin, C., Antoni, D., \& Negara, E. S. (2016). Comparison Route Redistribution on Dynamic Routing Protocol (EIGRP into OSPF and EIGRP into IS-IS). The 5th ICIBA 2016, International Conference on Information Technology and Engineering Application, 113119. Palembang: Universitas Bina Darma.

Mukmin, C., \& Negara, E. S. (2019). Analisis Kinerja Redistribusi Routing Protokol Dinamik. Klik Kumpulan Jurnal Ilmu Komputer, 6(3), 284$292 . \quad$ Retrieved from http://klik.ulm.ac.id/index.php/klik/article/ view/262

Munandar, A., \& Badrul, M. (2015). Penerapan Open Vpn Ipcop Sebagai Solusi Permasalahan Jaringan Pada Pt.Kimia Farma Trading \& Distribution. Jurnal Teknik Komputer AMIK BSI (JTK), 1(1), 30-41. Retrieved from https://ejournal.bsi.ac.id/ejurnal/index.php/ jtk/article/view/233

Pantu, Y., Iswahyudi, C., \& Rachmawati K, R. Y. (2015). ANALISIS DAN PERANCANGAN VLAN PADA DISHUBKOMINFO KABUPATEN MANGGARAI MENGGUNAKAN CISCO PACKET TRACER. Journal of Chemical Information and Modeling, 53(9), 1689-1699. https://doi.org/10.1017/CB0978110741532 4.004

Pratama, E. K. (2019). IMPLEMENTASI HOT STANDBY ROUTER PROTOCOL CISCO PADA JARINGAN THIN CLIENT. Jurnal Akrab Juara, 4(4), 160-168. Retrieved from http://akrabjuara.com/index.php/akrabjuar a/article/view/785

Purwanto, T. D. (2018). Analisis Kinerja Dynamic Routing pada Protokol Routing EIGRP untuk Menentukan Jalur Terbaik dengan Diffusing Update Algorithm (DUAL). JUITA: Jurnal Informatika, 6(2), 89. https://doi.org/10.30595/juita.v6i2.2902

Sari, S. P., Wijaya, A., Teknik, F., Komputer, I., \& Darma, U. B. (2017). Perbandingan Route Redistribute Protokol Routing Dinamik Pada IPv6 (Studi Kasus : EIGRP untuk IPv6 dengan OSPFV3 dan EIGRP dengan ISIS pada IPV6 ). 6, 382-391. 
Sugiyono. (2015). Metode Penelitian Kuantitatif dan Kualitatif dan $R \& D$ (Cetakan ke). Bandung: Alfabeta.

Wahyudi, D., Syamsuar, D., \& Negara, E. S. (2017). Perbandingan Redistribusi Routing Protokol Dinamis pada Exterior Gateway Protokol. Seminar Nasional Teknologi Dan Komunikasi, (30624), 179-185. 